\title{
METODE DMAIC SEBAGAI SOLUSI PENGENDALIAN KUALITAS PRODUKSI SEPATU TAMBANG: STUDI KASUS PT MANGUL JAYA-BEKASI
}

\author{
Hendy Tannady Tan \\ Department of Industrial Engineering, Faculty of Engineering, Binus University \\ Jln. K. H. Syahdan No. 9 Palmerah Jakarta Barat 11480 \\ hendy_tan3003@yahoo.com
}

\begin{abstract}
One way to increase profitability internally in PT Mangul Jaya - Bekasi is decreasing any costs produced from poor product quality by producing shoes with good quality. This study uses the DMAIC (define, measure, analyze, improve, control) method as a measuring tool. DMAIC is a quality improvement method that directly solves any problems related to the quality of a product even the primary cause of it. From the results of the study it is concluded that at the phase "define" shoes type Cheetah is the most problematic. Furthermore, on phase "measurement" it is identified that the Cp value of the Cheetah is below 1 which means that the process capability is low. After passing through the three sequencing steps (analyze, improve and control), finally this research is able to reduce the defects that occur in the shoes type Cheetah.
\end{abstract}

Keywords: profitability, product quality, process capability

\begin{abstract}
ABSTRAK
Salah satu cara peningkatan profitabilitas secara internal pada PT Mangul Jaya - Bekasi adalah menurunkan biaya yang diakibatkan oleh kualitas produk yang buruk dengan cara menghasilkan produk-produk sepatu yang berkualitas. Penelitian ini menggunakan metode DMAIC (define, measure, analyze, improve, control) sebagai alat ukur. DMAIC merupakan sebuah metode perbaikan kualitas yang langsung memecahkan masalah yang berkaitan dengan mutu sebuah produk hingga pada penyebab utamanya. Dari hasil penelitian disimpulkan bahwa pada tahap define diketahui produk sepatu yang paling bermasalah adalah sepatu tipe Cheetah. Pada tahap selanjutnya, yaitu measure diketahui bahwa nilai cp dari cheetah adalah dibawah 1 (kapabilitas proses masih rendah). Setelah melewati tahap-tahap berikutnya (analyze, improve dan control), akhirnya penelitian ini dapat menurunkan cacat yang terjadi pada sepatu tipe Cheetah.
\end{abstract}

Kata kunci: profitabilitas, kualitas produk, kapabilitas proses 


\section{PENDAHULUAN}

Mutu atau kualitas telah dikenal sejak empat ribu tahun lalu, ketika bangsa Mesir kuno mengukur dimensi batu-batu yang digunakan untuk membangun piramida. Pada jaman modern fungsi mutu berkembang melalui beberapa tahap (Ariani, Dorothea Wahyu., 1999:10), yaitu: (1) inspeksi konsep mutu modern dimulai pada tahun 1920-an, kelompok mutu yang utama adalah bagian inspeksi. Selama produksi, para inspektor mengukur hasil produksi berdasarkan spesifikasi; (2) pemastian mutu (quality assurance) - difokuskan untuk memastikan proses dan mutu produk melalui pelaksanaan audit operasi pelatihan, analisis kinerja teknis, dan petunjuk operasi untuk peningkatan mutu; (3) pengendalian mutu (quality control) - pada tahun 1940-an, kelompok inspeksi berkembang menjadi bagian pengendalian mutu. Adanya perang dunia II, mengharuskan produk militer bebas dari cacat. Tanggung jawab atas mutu dialihkan ke bagian Quality Control yang independen. Pada pemeriksa mutu dilengkapi dengan perangkat statistika seperti diagram kendali, dan penarikan sampel; (4) manajemen mutu - pemastian mutu bekerja berdasarkan status quo, sehingga upaya yang dilakukan hanyalah memastikan pelaksanaan pengendalian mutu, untuk itu aspek mutu perlu selalu dievaluasi dan direncanakan perbaikannya melalui penerapan fungsi-fungsi manajemen mutu; (5) manajemen mutu terpadu (total quality management) - dalam perkembangan manajemen mutu, ternyata tanggung jawab terhadap kualitas haruslah menjadi tanggung jawab setiap individu dalam perusahaan.

Sebuah pengendalian kualitas adalah tindakan yang harus dimulai dari pimpinan tertinggi organisasi dan bagaimana agar kualitas tersebut dapat menjadi budaya dan etos kerja sebuah organisasi merupakan syarat mutlak organisasi dan perusahaan saat ini. Kemampuan organisasi dalam menjaga kualitas produk baik saat produk tersebut berada di tangan konsumen, maupun kualitas pada saat work in process merupakan keharusan yang fundamental. Industri manufaktur dan jasa punya kewajiban yang sama dalam terus me-monitor kualitas dari output mereka. Ada delapan dimensi dari manufaktur dan empat dimensi dari industri jasa, apabila ditelusuri faktor-faktor tersebut akan mengerucut pada sebuah kata "kualitas". Dalam menjaga mutu dari produk yang dihasilkan, banyak sekali metode-metode yang dapat digunakan, penelitian ini membahas tentang bagaimana metode Define-Mesure-Analyze-Improve-Control (DMAIC) dapat menjadi sebuah solusi yang tepat bagi upaya-upaya memperbaiki kualitas, khususnya pada industry manufaktur. Penelitian ini dilakukan di sebuah perusahaan manufaktur yang memproduksi sepatu, yaitu PT Mangul Jaya, Bekasi. Sepatu yang diproduksi adalah sepatu yang biasanya digunakan oleh pekerja di daerah pertambangan. Dari data keluhan pelanggan, diperoleh beberapa masukan dan klaim dari konsumen yang kemudian dituangkan dalam Voice of Customer, ada beberapa jenis cacat sepatu yang ditemui saat sepatu sudah berada di tangan pelanggan. Cacat-cacat tersebut antara lain adalah: stitching, sole, wrinkle, colour, dan placement. Tujuan dari penelitian adalah memberikan solusi terbaik guna mereduksi jumlah cacat produk dengan metode DMAIC.

\section{METODE}

Penelitian menggunakan Voice of Customer sebagai tolak ukur definisi produk yang baik dimata costumer, kemudian dari data keluhan pelanggan diperoleh tentang spesifikasi dari jenis cacat yang sering ditemui pada objek sepatu. Dengan mengambil sampel langsung dari lantai produksi akan diperoleh rekap tentang nilai sigma dari setiap jenis sepatu tambang. Penelitian pada akhirnya akan mengerucut pada jenis sepatu yang memiliki nilai sigma terkecil. Dari objek dengan sigma terkecil inilah kemudian akan dianalisis penyebab cacat produk, improvisasi yang dilakukan dan bagaimana tahap pengendalian terhadap kualitas dijalankan. Tahapan analisis menggunakan ishikawa diagram dan Failure Mode Effect Analysis (FMEA) sebagai alat supportive, serta Design of Experiment dan checklist untuk bagian improvisasi dan control. 


\section{Statistical Process Control (SPC)}

Statistik adalah seni pengambilan keputusan tentang suatu proses atau populasi berdasarkan suatu analisis informasi yang terkandung di dalam suatu sampel dari populasi itu. Statistik adalah bahasa yang digunakan oleh insinyur, pengembangan, pembuatan, pengusahaan, manajemen, dan komponen-komponen fungsional bisnis yang lain untuk berkomunikasi tentang kualitas (Montgomery, 2002).

\section{Six Sigma}

Pada tahun 1980-an dan 1990-an, Motorolla merupakan salah satu dari banyak korporat AS dan Eropa dimana produk yang mereka luncurkan selalu kalah oleh para pesaing Jepang. Para pemimpin Motorolla mengakui bahwa kualitas produknya "mengerikan" (Pande et al., 2003). Seperti banyak perusahaan saat itu, Motorolla tidak mempunyai sebuah program kualitas, tetapi sejak 1987, keluar sebuah pendekatan baru dari sektor komunikasi Motorolla yang disebut Six Sigma- pada saat itu dikepalai George Fisher, yang kemudian menjadi Top Executive di Kodak. Dengan dukungan kuat dari chairman Motorolla, Bob Galvin- Six Sigma memberikan otot ekstra kepada Motorolla untuk mencapai tujuan-tujuan yang pada saat itu sepertinya tidak mungkin: target awal pada awal tahun 1980-an adalah sebesar sepuluh kali peningkatan pada lima tahun, diperkecil menjadi tujuan sepuluh kali peningkatan setiap dua tahun, atau 100 kali dalam empat tahun. Meskipun sasaran Six Sigma penting, tetapi perhatian lebih banyak diberikan kepada rata-rata peningkatan dalam proses dan produk (S.T, Miranda, 2002:16).

\section{Pengumpulan Data}

Pengumpulan data meliputi pengumpulan data primer dan data sekunder. Namun dalam makalah penyajian data hanya dibatasi pada data-data primer yang akan digunakan untuk proses perhitungan dan pengolahan data. Data-data yang dimaksud antara lain adalah data produksi sepatu (Tabel 1), data keluhan pelanggan (Tabel 2) dan data pengamatan cacat sepatu (Tabel 3).

Tabel 1

Data Produksi Sepatu

\begin{tabular}{lllllll}
\hline \multirow{2}{*}{ Bulan } & \multicolumn{2}{l}{ Tipe Sepatu } & \multicolumn{2}{l}{ Jumlah } \\
\cline { 2 - 7 } & Cheetah & Kings & Krusher & Gold & Star & \\
\hline Januari & 18281 & - & 12358 & 12675 & 12267 & 55581 \\
\hline Februari & 18511 & - & 13533 & 13413 & 14026 & 59483 \\
\hline Maret & 18030 & 18030 & 12919 & 12778 & 11711 & 73468 \\
\hline April & - & 27901 & 19425 & 19474 & - & 66800 \\
\hline Mei & - & 27696 & - & - & - & 27696 \\
\hline Juni & - & 19780 & - & - & - & 19780 \\
\hline Juli & 37214 & - & 27917 & - & 26451 & 91582 \\
\hline Agustus & 37229 & - & 27042 & - & 26596 & 90867 \\
\hline September & 36971 & - & 25714 & 27316 & 28071 & 118072 \\
\hline Oktober & 37185 & 26320 & - & 25496 & - & 89001 \\
\hline November & 37161 & 26290 & - & 26530 & - & 89981 \\
\hline Desember & 36605 & 26311 & - & 26598 & - & 89514 \\
\hline Jumlah & 277187 & 172328 & 138908 & 164280 & 119122 & $\mathbf{8 7 1 8 2 5}$ \\
\hline
\end{tabular}


Tabel 2

Rekap Data Keluhan Pelanggan Sepatu

\begin{tabular}{lllllll}
\hline \multirow{2}{*}{ Jenis Sepatu } & \multicolumn{2}{l}{ Defect Category } & & & \multirow{2}{*}{ Total } \\
\cline { 2 - 6 } & Stitching & Sole & Wrinkle & Color & Placement & \\
\hline Cheetah & 337 & 194 & 126 & 52 & 25 & 734 \\
\hline Kings & 150 & 114 & 67 & 35 & 41 & 407 \\
\hline Krusher & 78 & 63 & 39 & 15 & 19 & 214 \\
\hline Gold & 93 & 70 & 46 & 25 & 17 & 251 \\
\hline Star & 69 & 55 & 40 & 12 & 21 & 197 \\
\hline
\end{tabular}

Tabel 3

Rekap Data Hasil Pengamatan Lapangan Cacat Sepatu

\begin{tabular}{lcccc}
\hline Jenis Sepatu & $\begin{array}{l}\text { Jumlah } \\
\text { Inspeksi }\end{array}$ & Stitching & Sole & Wrinkle \\
\hline Cheetah & 4000 & 75 & 50 & 42 \\
\hline Kings & 4000 & 70 & 50 & 27 \\
\hline Krusher & 4000 & 38 & 34 & 31 \\
\hline Gold & 4000 & 47 & 42 & 33 \\
\hline Star & 4000 & 47 & 47 & 39 \\
\hline
\end{tabular}

\section{HASIL DAN PEMBAHASAN}

\section{Tahapan Define}

Tahapan Define dilakukan dengan melakukan perhitungan level sigma. Perhitungan nilai sigma diperoleh berdasarkan tabel konversi DPMO ke nilai sigma (Tabel 4). Dibawah ini adalah formula untuk mencari nilai Defect per Unit (DPU), Total Opportunities (TOP), Defect per Opportunities (DPO), dan Defect per Million Opportunities (DPMO).

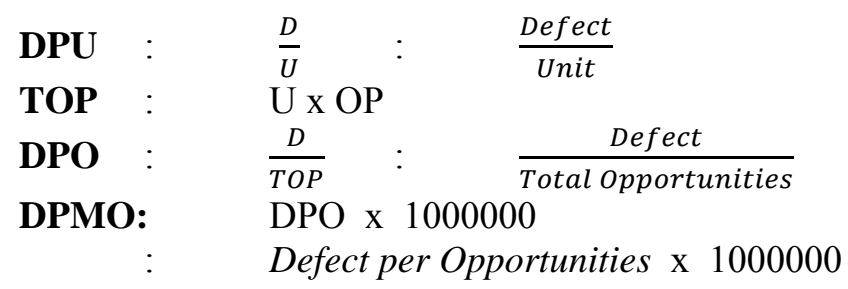

Tabel 4

Rekap Perhitungan DPMO dan Level Sigma Sepatu

\begin{tabular}{ccccccccc}
\hline $\begin{array}{c}\text { Tipe } \\
\text { Sepatu }\end{array}$ & Produksi & $\begin{array}{c}\text { Total } \\
\text { Cacat }\end{array}$ & $\begin{array}{c}\text { Persentase } \\
\text { Cacat }\end{array}$ & DPU & TOP & DPO & DPMO & $\begin{array}{c}\text { Level } \\
\text { Sigma }\end{array}$ \\
\hline Cheetah & 277187 & 734 & 0.265 & 0.00265 & 2771870 & 0.000265 & 265 & 2.13 \\
\hline Kings & 172328 & 407 & 0.236 & 0.00236 & 1723280 & 0.000236 & 236 & 2.22 \\
\hline Krusher & 138908 & 214 & 0.154 & 0.00154 & 1389080 & 0.000154 & 154 & 2.52 \\
\hline Gold & 164280 & 251 & 0.153 & 0.00153 & 1642800 & 0.000153 & 153 & 2.53 \\
\hline
\end{tabular}




\begin{tabular}{ccccccccc}
\hline Star & 119122 & 197 & 0.165 & 0.00165 & 1191220 & 0.000165 & 165 & 2.48 \\
\hline Jumlah & $\mathbf{8 7 1 8 2 5}$ & $\mathbf{1 8 0 3}$ & & & & & &
\end{tabular}

Nilai sigma terkecil adalah pada sepatu Cheetah (Tabel 5). Selanjutnya penelitian difokuskan pada sepatu jenis ini. Setelahnya kita cari apa saja penyebab terjadinya cacat, untuk kemudian kita identifikasi faktor yang dominan.

Tabel 5

Persentase Kumulatif Jenis Cacat Sepatu Cheetah

\begin{tabular}{|c|c|c|c|}
\hline Jenis Cacat & Frekuensi & Kumulatif & Persentase (\%) \\
\hline Stitching & 337 & 337 & 45.9 \\
\hline Sole & 194 & 531 & 26.4 \\
\hline Wrinkle & 126 & 657 & 17.1 \\
\hline Color & 52 & 709 & 7.08 \\
\hline Placement & 25 & 734 & 3.52 \\
\hline Jumlah & \multicolumn{2}{|c|}{734} & 100 \\
\hline
\end{tabular}

Dari tabel diatas terlihat bahwa jenis cacat yang dominan adalah cacat yang disebabkan jahitan yang tidak rapi (Stitching), yaitu dengan persentase sebesar 45.9\%, kemudian Sol yang tidak merekat dengan baik (26.4\%), dan cacat kulit mengkerut (17.2\%), dimana total persentase ketiganya adalah $89.4 \%$. Ketiga cacat dominan tersebut dikategorikan sebagai critical to quality (CTQ).

\section{Tahapan Measure}

Measure merupakan langkah operasional kedua dalam program peningkatan kualitas Six Sigma. Hal-hal pokok dan mendasar yang harus dilakukan adalah mengukur kapabilitas proses (Process Capability/CP) dan mengukur kinerja sekarang (Baseline) (Tabel 6 - 8). Di bawah ini adalah peta kendali NP dan nilai Process Capability dari setiap jenis cacat yang termasuk dalam Critical to Quality (CTQ) (Gambar 1 - 3).

Tabel 6

Data Proporsi Cacat Jahitan (Stitching)

\begin{tabular}{ccccccc}
\hline $\begin{array}{c}\text { Tanggal } \\
\text { Observasi }\end{array}$ & Jumlah Inspeksi & $\begin{array}{c}\text { Cacat } \\
\text { Jahitan }\end{array}$ & $\begin{array}{c}\text { Proporsi } \\
\text { Cacat }\end{array}$ & UCL & LCL & $\begin{array}{c}\text { Persentase Cacat } \\
(\%)\end{array}$ \\
\hline 10 Maret 2009 & 200 & 2 & 0.010 & 9.5 & 0 & 1.000 \\
\hline 11 Maret 2009 & 200 & 2 & 0.010 & 9.5 & 0 & 1.000 \\
\hline 12 Maret 2009 & 200 & 3 & 0.015 & 9.5 & 0 & 1.500 \\
\hline 13 Maret 2009 & 200 & 10 & 0.050 & 9.5 & 0 & 5.000 \\
\hline 16 Maret 2009 & 200 & 2 & 0.010 & 9.5 & 0 & 1.000 \\
\hline 17 Maret 2009 & 200 & 3 & 0.015 & 9.5 & 0 & 1.500 \\
\hline 18 Maret 2009 & 200 & 8 & 0.040 & 9.5 & 0 & 4.000 \\
\hline 19 Maret 2009 & 200 & 3 & 0.015 & 9.5 & 0 & 1.500 \\
\hline 20 Maret 2009 & 200 & 3 & 0.015 & 9.5 & 0 & 1.500 \\
\hline 23 Maret 2009 & 200 & 8 & 0.040 & 9.5 & 0 & 4.000 \\
\hline 24 Maret 2009 & 200 & 6 & 0.030 & 9.5 & 0 & 3.000 \\
\hline 25 Maret 2009 & 200 & 3 & 0.015 & 9.5 & 0 & 1.500 \\
\hline 30 Maret 2009 & 200 & 2 & 0.010 & 9.5 & 0 & 1.000 \\
\hline 31 Maret 2009 & 200 & 3 & 0.015 & 9.5 & 0 & 1.500 \\
\hline 1 April 2009 & 200 & 6 & 0.030 & 9.5 & 0 & 3.000 \\
\hline
\end{tabular}




\begin{tabular}{|c|c|c|c|c|c|c|c|c|}
\hline \multicolumn{2}{|c|}{2 April 2009} & \multicolumn{2}{|c|}{200} & 2 & 0.010 & 9.5 & 0 & 1.000 \\
\hline \multicolumn{2}{|c|}{3 April 2009} & \multicolumn{2}{|c|}{200} & 3 & 0.015 & 9.5 & 0 & 1.500 \\
\hline \multicolumn{2}{|c|}{6 April 2009} & \multicolumn{2}{|c|}{200} & 1 & 0.005 & 9.5 & 0 & 0.500 \\
\hline \multicolumn{2}{|c|}{7 April 2009} & \multicolumn{2}{|c|}{200} & 2 & 0.010 & 9.5 & 0 & 1.000 \\
\hline \multirow{2}{*}{\multicolumn{2}{|c|}{ Jumlah }} & \multirow{2}{*}{\multicolumn{2}{|c|}{4000}} & 75 & 0.375 & & & \\
\hline & & & & $=0.01$ & & & & \\
\hline CLp & : & \multicolumn{3}{|c|}{$\begin{array}{l}0.018 \\
\text { Total Defect }\end{array}$} & & & & \\
\hline CLnp & : & \multicolumn{3}{|c|}{$\frac{\text { Total Defect }}{\text { Total Hari Observasi }}=3.75$} & & & & \\
\hline \multirow[t]{2}{*}{ UCL } & : & CLnp & $+3 \sqrt{ }$ & $\overline{C L p)}$ & & & & \\
\hline & $\begin{array}{l}: \\
:\end{array}$ & $\begin{array}{l}3.75 \\
9.5\end{array}$ & $+3 \sqrt{ }$ & $\overline{0.018)}$ & & & & \\
\hline \multirow[t]{3}{*}{ LCL } & : & CLnp & $-3 \sqrt{ }$ & $\overline{C L p)}$ & & & & \\
\hline & : & 3.75 & $-3 \sqrt{ }$ & $\overline{018)}$ & & & & \\
\hline & : & $-2 \sim 0$ & & & & & & \\
\hline
\end{tabular}

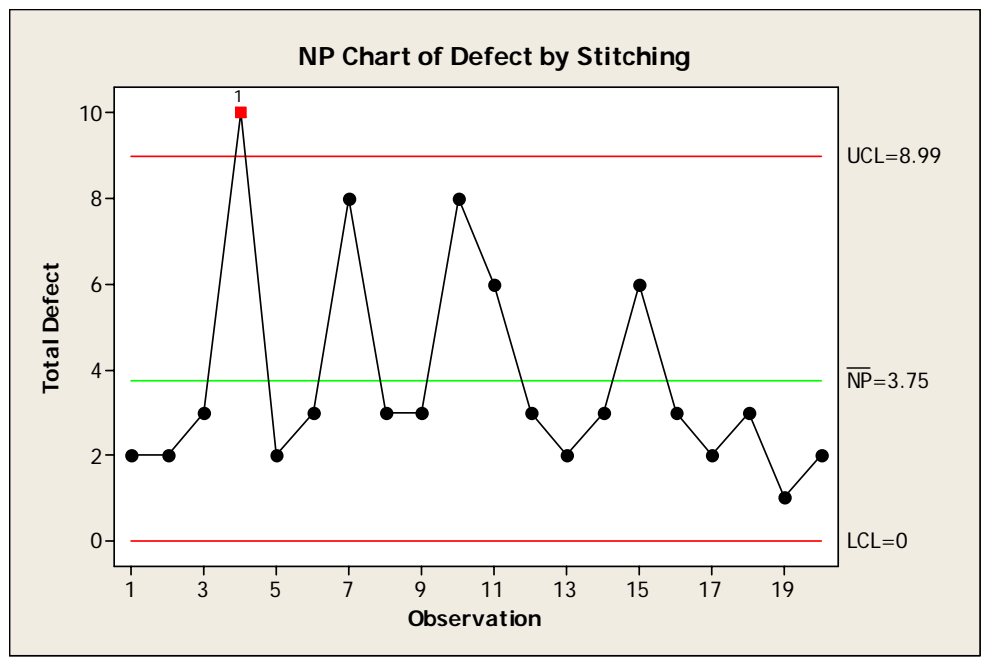

Gambar 1. Peta kendali NP untuk cacat jahitan sebelum implementasi.
Kapabilitas Proses
$=$
$1-0.018$
$=0.982$
Defect per Unit
$=\mathrm{D} / \mathrm{U}$
$=$
0.018

Tabel 7

Data Proporsi Cacat Sol Tidak Lengket (Sole)

\begin{tabular}{ccccccc}
\hline $\begin{array}{c}\text { Tanggal } \\
\text { Observasi }\end{array}$ & $\begin{array}{c}\text { Jumlah } \\
\text { Inspeksi }\end{array}$ & $\begin{array}{c}\text { Cacat Sol Tidak } \\
\text { Lengket }\end{array}$ & $\begin{array}{c}\text { Proporsi } \\
\text { Cacat }\end{array}$ & UCL & LCL & $\begin{array}{c}\text { Persentase Cacat } \\
\text { (\%) }\end{array}$ \\
\hline 10 Maret 2009 & 200 & 1 & 0.005 & 7.2 & 0 & 0.500 \\
\hline 11 Maret 2009 & 200 & 7 & 0.035 & 7.2 & 0 & 3.500 \\
\hline 12 Maret 2009 & 200 & 2 & 0.010 & 7.2 & 0 & 1.000 \\
\hline 13 Maret 2009 & 200 & 2 & 0.010 & 7.2 & 0 & 1.000 \\
\hline 16 Maret 2009 & 200 & 6 & 0.030 & 7.2 & 0 & 3.000 \\
\hline 17 Maret 2009 & 200 & 1 & 0.005 & 7.2 & 0 & 0.500 \\
\hline 18 Maret 2009 & 200 & 1 & 0.005 & 7.2 & 0 & 0.500 \\
\hline 19 Maret 2009 & 200 & 4 & 0.020 & 7.2 & 0 & 2.000 \\
\hline 20 Maret 2009 & 200 & 1 & 0.005 & 7.2 & 0 & 0.500 \\
\hline 23 Maret 2009 & 200 & 1 & 0.005 & 7.2 & 0 & 0.500 \\
\hline 24 Maret 2009 & 200 & 8 & 0.040 & 7.2 & 0 & 4.000 \\
\hline 25 Maret 2009 & 200 & 3 & 0.015 & 7.2 & 0 & 1.500 \\
\hline
\end{tabular}




\begin{tabular}{ccccccc}
\hline 27 Maret 2009 & 200 & 2 & 0.010 & 7.2 & 0 & 1.000 \\
\hline 30 Maret 2009 & 200 & 2 & 0.010 & 7.2 & 0 & 1.000 \\
\hline 31 Maret 2009 & 200 & 5 & 0.025 & 7.2 & 0 & 2.500 \\
\hline 1 April 2009 & 200 & 2 & 0.010 & 7.2 & 0 & 1.000 \\
\hline 2 April 2009 & 200 & 1 & 0.005 & 7.2 & 0 & 0.500 \\
\hline 3 April 2009 & 200 & 1 & 0.005 & 7.2 & 0 & 0.500 \\
\hline 6 April 2009 & 200 & - & 0.000 & 7.2 & 0 & 0.000 \\
\hline 7 April 2009 & 200 & - & 0.000 & 7.2 & 0 & 0.000 \\
\hline Jumlah & $\mathbf{4 0 0 0}$ & $\mathbf{5 0}$ & & &
\end{tabular}

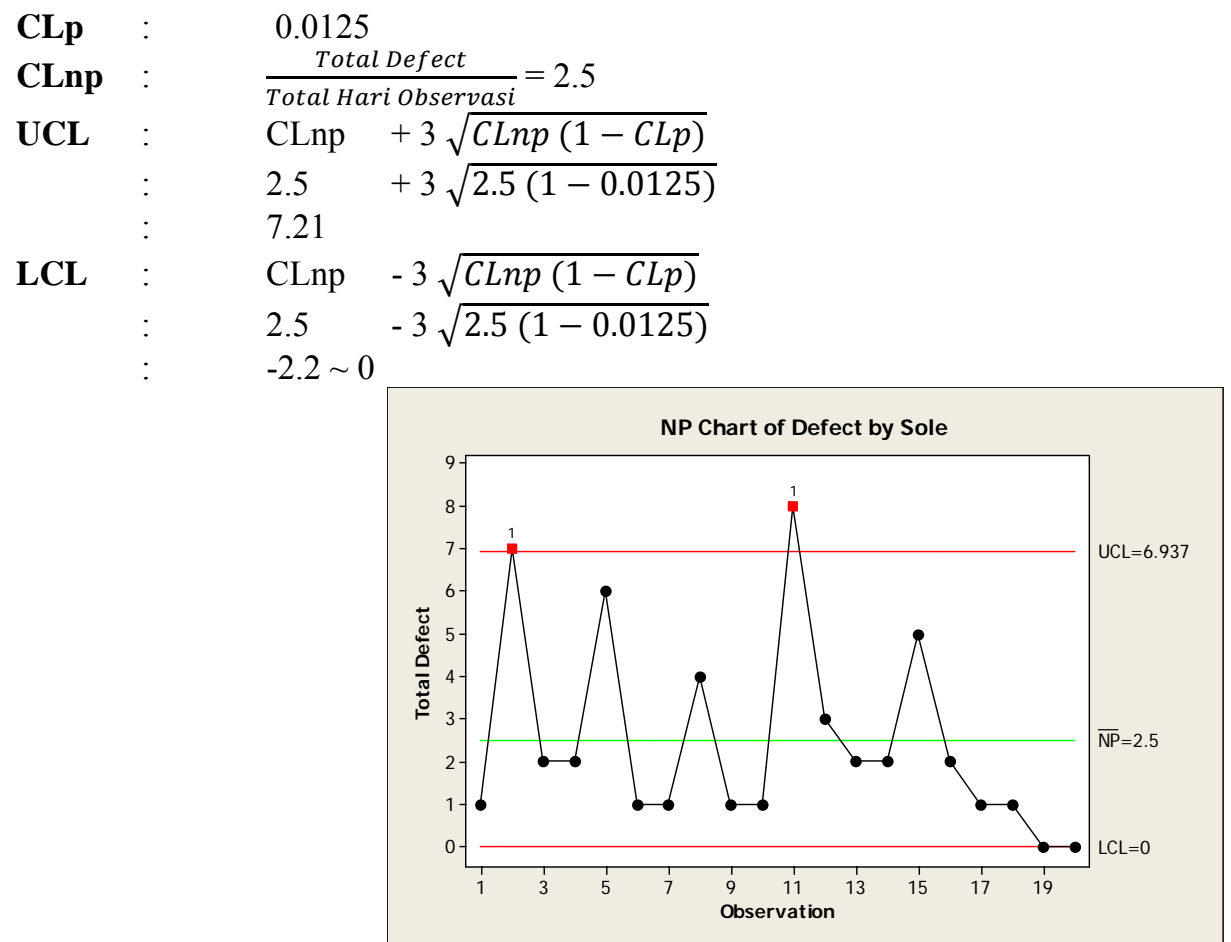

Gambar 2. Peta kendali NP untuk cacat sol sebelum implementasi.
Kapabilitas Proses
$=$
$1-0.0125$
$=$
0.9875
Defect per Unit
$=\mathrm{D} / \mathrm{U}$
0.0125

Tabel 8

Data Proporsi Cacat Kulit Mengkerut (Wrinkle)

\begin{tabular}{ccccccc}
\hline Tanggal Observasi & $\begin{array}{c}\text { Jumlah } \\
\text { Inspeksi }\end{array}$ & $\begin{array}{c}\text { Cacat Kulit } \\
\text { Mengkerut }\end{array}$ & $\begin{array}{c}\text { Proporsi } \\
\text { Cacat }\end{array}$ & UCL & LCL & $\begin{array}{c}\text { Persentase } \\
\text { Cacat (\%) }\end{array}$ \\
\hline 10 Maret 2009 & 200 & 2 & 0.010 & 6.4 & 0 & 1.000 \\
\hline 11 Maret 2009 & 200 & 1 & 0.005 & 6.4 & 0 & 0.500 \\
\hline 12 Maret 2009 & 200 & 2 & 0.010 & 6.4 & 0 & 1.000 \\
\hline 13 Maret 2009 & 200 & 2 & 0.010 & 6.4 & 0 & 1.000 \\
\hline 16 Maret 2009 & 200 & 5 & 0.025 & 6.4 & 0 & 2.500 \\
\hline 17 Maret 2009 & 200 & 2 & 0.010 & 6.4 & 0 & 1.000 \\
\hline 18 Maret 2009 & 200 & 1 & 0.005 & 6.4 & 0 & 0.500 \\
\hline 19 Maret 2009 & 200 & 2 & 0.010 & 6.4 & 0 & 1.000 \\
\hline 20 Maret 2009 & 200 & 2 & 0.010 & 6.4 & 0 & 1.000 \\
\hline 23 Maret 2009 & 200 & 1 & 0.005 & 6.4 & 0 & 0.500
\end{tabular}




\begin{tabular}{ccccccc}
\hline 24 Maret 2009 & 200 & 1 & 0.005 & 6.4 & 0 & 0.500 \\
\hline 25 Maret 2009 & 200 & 1 & 0.005 & 6.4 & 0 & 0.500 \\
\hline 27 Maret 2009 & 200 & - & 0.000 & 6.4 & 0 & 0.000 \\
\hline 30 Maret 2009 & 200 & 2 & 0.010 & 6.4 & 0 & 1.000 \\
\hline 31 Maret 2009 & 200 & 6 & 0.030 & 6.4 & 0 & 3.000 \\
\hline 1 April 2009 & 200 & 3 & 0.015 & 6.4 & 0 & 1.500 \\
\hline 2 April 2009 & 200 & 1 & 0.005 & 6.4 & 0 & 0.500 \\
\hline 3 April 2009 & 200 & 6 & 0.030 & 6.4 & 0 & 3.000 \\
\hline 6 April 2009 & 200 & 2 & 0.010 & 6.4 & 0 & 1.000 \\
\hline 7 April 2009 & 200 & - & 0.000 & 6.4 & 0 & 0.000 \\
\hline Jumlah & $\mathbf{4 0 0 0}$ & $\mathbf{4 2}$ & & &
\end{tabular}

$\begin{array}{llll}\text { CLp } & : & 0.01 \\ \text { CLnp } & : & \frac{\text { Total Defect }}{\text { Total Hari Observasi }}=2.1 \\ \text { UCL } & : & \text { CLnp } \quad+3 \sqrt{C \operatorname{Lnp}(1-C L p)} \\ & : & 2.1 \quad+3 \sqrt{2.1(1-0.01)} \\ & : & 6.4 & \\ \text { LCL } & : & \text { CLnp }-3 \sqrt{C \operatorname{Cn} p(1-C L p)} \\ & : & 2.5 \quad-3 \sqrt{2.1(1-0.01)} \\ & : & -2.2 \sim 0\end{array}$

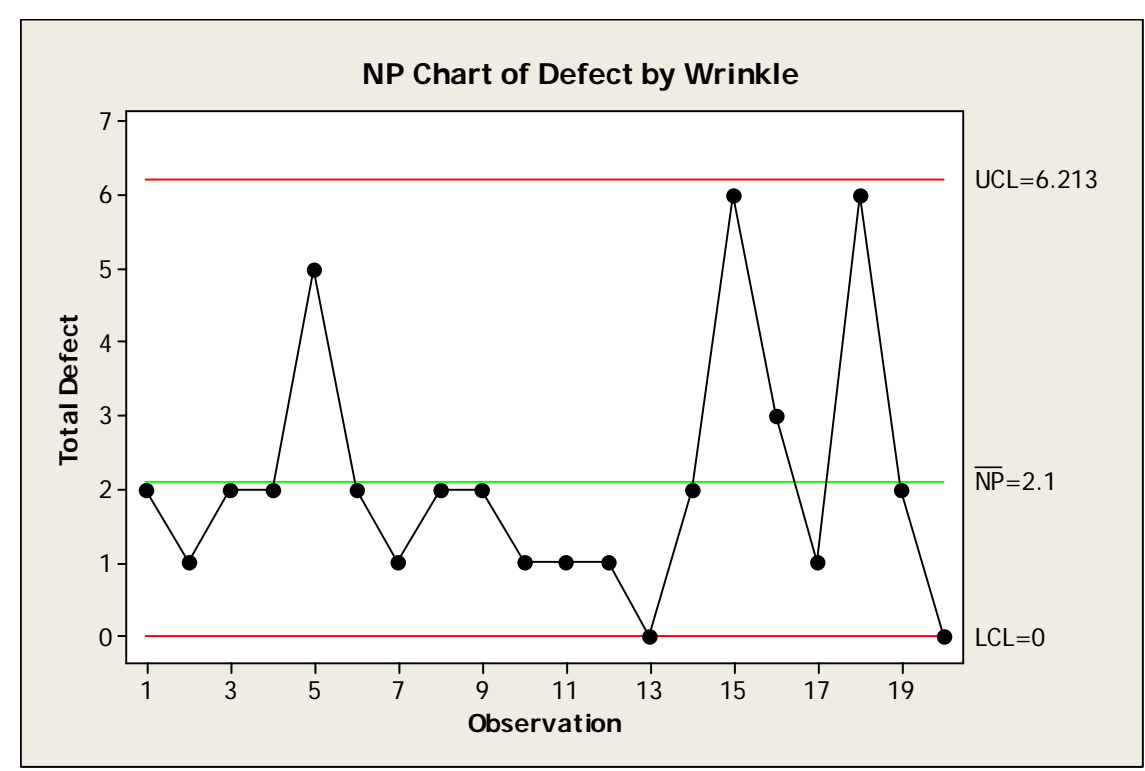

Gambar 3. Peta kendali NP untuk cacat kulit mengkerut sebelum implementasi.

$\begin{array}{lllll}\text { Kapabilitas Proses } & = & 1-0.01 & = & 0.99 \\ \text { Defect per Unit } & = & \mathrm{D} / \mathrm{U} & = & 0.01\end{array}$

\section{Tahapan Analyze}

\section{Brainstorming}

Brainstorming dilakukan dengan tujuan mengetahui terjadinya penyebab-penyebab cacat, dan dilakukan dengan pihak-pihak yang yang terkait pada proses produksi sepatu. Hasil Brainstorming dapat dilihat pada Tabel 9. 
Tabel 9

Hasil Brainstorming Cacat Jahitan, Sol, dan Kulit Mengkerut

\begin{tabular}{|c|c|c|c|}
\hline \multicolumn{4}{|c|}{ Cacat Jahitan } \\
\hline Faktor & Penyebab 1 & Penyebab 2 & Penyebab 3 \\
\hline Machine & Mesin jahit tidak bekerja dengan baik & $\begin{array}{l}\text { Penyetingan mesin jahit yang } \\
\text { tidak tepat }\end{array}$ & $\begin{array}{l}\text { Metode Skiving } \\
\text { tidak tepat }\end{array}$ \\
\hline Method & $\begin{array}{l}\text { Metode penggantian jarum jahit } \\
\text { yangberulang-ulang }\end{array}$ & - & - \\
\hline Man & $\begin{array}{l}\text { Operator kurang memperhatikan } \\
\text { instruksi pekerjaan }\end{array}$ & - & - \\
\hline Material & Spesifikasi material tidak sesuai & $\begin{array}{l}\text { Penggunaan jarum dan benang } \\
\text { kualitas kedua }\end{array}$ & - \\
\hline \multicolumn{4}{|c|}{ Sol Tidak Lengket } \\
\hline Faktor & Penyebab 1 & Penyebab 2 & Penyebab 3 \\
\hline Machine & Chillers kurang dingin & - & - \\
\hline Method & Metode pengeleman salah & - & - \\
\hline Man & Pekerja kurang terampil & Terjadinya kecerobohan & - \\
\hline Material & Mutu lem kurang baik & - & - \\
\hline \multicolumn{4}{|c|}{ Kulit Mengkerut } \\
\hline Faktor & Penyebab 1 & Penyebab 2 & Penyebab 3 \\
\hline Method & $\begin{array}{l}\text { Metode peletakkan menjahit yang tidak } \\
\text { benar }\end{array}$ & $\begin{array}{l}\text { Metode pemotongan kulit tidak } \\
\text { sesuai }\end{array}$ & - \\
\hline Man & Rendahnya konsentrasi pekerja & - & - \\
\hline Material & $\begin{array}{l}\text { Cacat produk dari pemasok yang lolos } \\
\text { QC }\end{array}$ & - & - \\
\hline
\end{tabular}

\section{FMEA (Failure Mode and Effect Analysis)}

FMEA bertujuan untuk mengetahui sebesar apa dampak dari penyebab masalah terhadap sistem. Tabel 10, 11, dan 12 memperlihatkan FMEA padea ketiga jenis cacat.

Tabel 10

Formulir FMEA untuk Cacat Jahitan

\begin{tabular}{|c|c|c|c|c|c|c|c|c|}
\hline \multirow[b]{2}{*}{ CTQ } & \multirow{2}{*}{$\begin{array}{c}\text { Efek Kegagalan } \\
\text { Potensial }\end{array}$} & \multirow{2}{*}{$\begin{array}{c}\text { Modus } \\
\text { Kegagalan } \\
\text { Potensial } \\
\end{array}$} & \multirow{2}{*}{$\begin{array}{l}\text { Penyebab } \\
\text { Potensial }\end{array}$} & \multicolumn{3}{|c|}{ Nilai } & \multirow[b]{2}{*}{ RPN } & \multirow[b]{2}{*}{ Rekomendasi } \\
\hline & & & & $\mathbf{S}$ & $\mathbf{O}$ & D & & \\
\hline \multirow{3}{*}{$\begin{array}{l}\text { Cacat } \\
\text { Jahitan }\end{array}$} & $\begin{array}{l}\text { Settingan mesin } \\
\text { kurang tepat }\end{array}$ & $\begin{array}{l}\text { Ketidaktelitian } \\
\text { operator }\end{array}$ & $\begin{array}{l}\text { Tidak ada } \\
\text { peletakkan } \\
\text { SOP } \\
\end{array}$ & 5 & 5 & 5 & 125 & $\begin{array}{l}\text { Mulainya dilakukan } \\
\text { peletakkan SOP untuk } \\
\text { membantu pekerja }\end{array}$ \\
\hline & $\begin{array}{l}\text { Spesifikasi } \\
\text { kulit/sol tidak } \\
\text { sesuai }\end{array}$ & $\begin{array}{l}\text { Kesalahan } \\
\text { proses Skiving }\end{array}$ & Human Error & 6 & 3 & 2 & 36 & $\begin{array}{l}\text { Perlu dilakukan } \\
\text { pengawsan pekerjaan } \\
\text { lebih ketat lagi } \\
\text { terhadap operator dan } \\
\text { pemberian instruksi } \\
\text { diperjelas saat } \\
\text { melakukan briefing } \\
\text { sebelum dimulai } \\
\text { pekerjaan }\end{array}$ \\
\hline & $\begin{array}{l}\text { Pekerja kurang } \\
\text { memperhatikan } \\
\text { instruksi } \\
\text { pekerjaan }\end{array}$ & Human Error & $\begin{array}{l}\text { Kurang } \\
\text { pengawasan } \\
\text { dari foreman }\end{array}$ & 6 & 6 & 6 & 216 & $\begin{array}{l}\text { Foreman perlu } \\
\text { melakukan pengawasan } \\
\text { lebih ketat lagi dan } \\
\text { menegur serta }\end{array}$ \\
\hline
\end{tabular}


memberitahukan cara pengerjaan yang benar jika dilihat ada yang melakukan kekeliruan

Metode skiving tidak tepat Human Error

Operator

kurang

mendapatkan pelatihan kerja

Tabel 11

Formulir FMEA untuk Sol Tidak Lengket

\begin{tabular}{|c|c|c|c|c|c|c|c|c|}
\hline \multirow[b]{2}{*}{ CTQ } & \multirow{2}{*}{$\begin{array}{c}\text { Efek } \\
\text { Kegagalan } \\
\text { Potensial }\end{array}$} & \multirow{2}{*}{$\begin{array}{c}\text { Modus } \\
\text { Kegagalan } \\
\text { Potensial }\end{array}$} & \multirow{2}{*}{$\begin{array}{l}\text { Penyebab } \\
\text { Potensial }\end{array}$} & \multicolumn{3}{|c|}{ Nilai } & \multirow[b]{2}{*}{ RPN } & \multirow[b]{2}{*}{ Rekomendasi } \\
\hline & & & & $\mathbf{S}$ & $\mathbf{O}$ & D & & \\
\hline \multirow{4}{*}{$\begin{array}{l}\text { Sol } \\
\text { Tidak } \\
\text { Lengket }\end{array}$} & $\begin{array}{l}\text { Chillers } \\
\text { kurang dingin }\end{array}$ & Chillers kotor & $\begin{array}{c}\text { Kurang } \\
\text { perawatan }\end{array}$ & 6 & 6 & 5 & 180 & $\begin{array}{l}\text { Perlu dibuat jadwal perawatan } \\
\text { dalam bentuk harian, mingguan, } \\
\text { atau bulanan untuk chillers } \\
\text { secara rutin }\end{array}$ \\
\hline & $\begin{array}{l}\text { Mutu lem } \\
\text { kurang baik }\end{array}$ & $\begin{array}{l}\text { Campuran lem } \\
\text { tidak sesuai }\end{array}$ & $\begin{array}{l}\text { Operator } \\
\text { kurang teliti }\end{array}$ & 4 & 3 & 2 & 24 & $\begin{array}{l}\text { Perlu adanya foreman sebagai } \\
\text { pengawas pada saat } \\
\text { pencampuran lem dilakukan }\end{array}$ \\
\hline & $\begin{array}{l}\text { Operator } \\
\text { sering } \\
\text { melakukan } \\
\text { kesalahan }\end{array}$ & $\begin{array}{l}\text { Kurang } \\
\text { terampil } \\
\text { melakukan } \\
\text { pekerjaan }\end{array}$ & $\begin{array}{l}\text { Kurang } \\
\text { pelatihan }\end{array}$ & 4 & 3 & 4 & 48 & $\begin{array}{l}\text { Segera mungkin diberikan } \\
\text { pelatihan tambahan }\end{array}$ \\
\hline & $\begin{array}{l}\text { Metode } \\
\text { pengeleman } \\
\text { keliru }\end{array}$ & Human Error & $\begin{array}{l}\text { Tidak adanya } \\
\text { pengawasan } \\
\text { dari Foreman }\end{array}$ & 3 & 2 & 2 & 12 & $\begin{array}{l}\text { Sebaiknya dilakukan } \\
\text { pengawasan lebih ketat lagi } \\
\text { terhadap cara kerja operator }\end{array}$ \\
\hline
\end{tabular}

Tabel 12

Formulir FMEA untuk Kulit Mengkerut

\begin{tabular}{|c|c|c|c|c|c|c|c|c|}
\hline \multirow[b]{2}{*}{ CTQ } & \multirow{2}{*}{$\begin{array}{c}\text { Efek } \\
\text { Kegagalan } \\
\text { Potensial } \\
\end{array}$} & \multirow{2}{*}{$\begin{array}{c}\text { Modus } \\
\text { Kegagalan } \\
\text { Potensial } \\
\end{array}$} & \multirow{2}{*}{$\begin{array}{l}\text { Penyebab } \\
\text { Potensial }\end{array}$} & \multicolumn{3}{|c|}{ Nilai } & \multirow[b]{2}{*}{ RPN } & \multirow[b]{2}{*}{ Rekomendasi } \\
\hline & & & & $\mathbf{S}$ & $\mathbf{O}$ & D & & \\
\hline \multirow{3}{*}{$\begin{array}{c}\text { Cacat } \\
\text { Kulit } \\
\text { Mengkerut }\end{array}$} & $\begin{array}{l}\text { Cacat material } \\
\text { dari supplier } \\
\text { yang lolos QC }\end{array}$ & $\begin{array}{l}\text { Inspeksi tidak } \\
\text { ketat }\end{array}$ & $\begin{array}{l}\text { Penyampaian } \\
\text { informasi } \\
\text { pemesanan } \\
\text { yang kurang } \\
\text { jelas } \\
\end{array}$ & 4 & 5 & 5 & 80 & $\begin{array}{l}\text { Sebaiknya dilakukan perbaikan } \\
\text { cara penyampaian informasi yang } \\
\text { benar kepada supplier tentang } \\
\text { pemesanan material dan dilakukan } \\
\text { inspeksi lebih teliti lagi }\end{array}$ \\
\hline & $\begin{array}{c}\text { Metode } \\
\text { penjahitan } \\
\text { tidak sesuai } \\
\end{array}$ & Human Error & $\begin{array}{c}\text { Tidak ada } \\
\text { peletakkan } \\
\text { SOP }\end{array}$ & 5 & 5 & 2 & 50 & $\begin{array}{l}\text { Segera mungkin dilakukan } \\
\text { peletakkan SOP }\end{array}$ \\
\hline & $\begin{array}{l}\text { Operator } \\
\text { sering } \\
\text { melakukan } \\
\text { kesalahan }\end{array}$ & $\begin{array}{l}\text { Operator } \\
\text { kurang terampil } \\
\text { melakukan } \\
\text { pekerjaan }\end{array}$ & $\begin{array}{l}\text { Kurang } \\
\text { pelatihan }\end{array}$ & 4 & 4 & 4 & 64 & $\begin{array}{c}\text { Diberikan pelatihan secara berkala } \\
\text { dan terjadwal dengan baik }\end{array}$ \\
\hline
\end{tabular}

\section{Tahapan Improve}

Design Experiment untuk Cacat Jahitan

Tabel 13 berikut merupakan hasil pengamatan cacat jahitan karena cahaya, konsentrasi, dan kualitas benang dengan dua replikasi. 
Tabel 13

Hasil Pengamatan Cacat Jahitan Karena Cahaya, Konsentrasi, dan Kualitas Benang dengan Dua Replikasi

\begin{tabular}{ccccc}
\hline Faktor & \multicolumn{3}{c}{ Konsentrasi } \\
\hline \multirow{3}{*}{ Cahaya 20 Watt } & \multicolumn{2}{c}{ Rendah } & \multicolumn{2}{c}{ Tinggi } \\
\cline { 2 - 5 } & \multicolumn{2}{c}{ Kualitas Benang } & \multicolumn{2}{c}{ Kualitas Benang } \\
\cline { 2 - 5 } & Tipis & Tebal & Tipis & Tebal \\
\cline { 2 - 5 } & 15 & 14 & 12 & 8 \\
\cline { 2 - 5 } & 13 & 11 & 22 & 14 \\
\hline \multirow{2}{*}{ Jumlah } & 28 & 6 & 6 & 4 \\
\hline \multirow{2}{*}{ Cahaya 40 Watt } & 8 & 6 & 4 & 2 \\
\hline Jumlah & 7 & 12 & 10 & 6 \\
\hline
\end{tabular}

Keterangan: A (Cahaya), B (Konsentrasi), C (Kualitas Benang)
Maka Hasil Respon:
$(1)=28$
$\mathrm{a}=15 \quad \mathrm{~b}=22 \quad \mathrm{c}=25$

$\mathrm{Ab}=10$

$a c=12 \quad b c=14 \quad a b c=6$

Penentuan kontras untuk cacat jahitan dengan metode Yates disajikan pada Tabel 14, dan tabel Anovanya disajikan pada Tabel 15.

Tabel 14

Penentuan Kontras untuk Cacat Jahitan dengan Metode Yates

\begin{tabular}{crrrrr}
\hline Faktor & Hasil Respon & Kolom (1) & Kolom (2) & Kontras & JK \\
\hline$(1)$ & 28 & 43 & 75 & 132 & 1089 \\
\hline $\mathrm{A}$ & 15 & 32 & 57 & -46 & 132.25 \\
\hline $\mathrm{B}$ & 22 & 37 & -25 & -28 & 49 \\
\hline $\mathrm{AB}$ & 10 & 20 & -21 & 6 & 2.25 \\
\hline $\mathrm{C}$ & 25 & -13 & -11 & -18 & 20.25 \\
\hline $\mathrm{Ac}$ & 12 & -12 & -17 & 4 & 1 \\
\hline $\mathrm{Bc}$ & 14 & -13 & 1 & -6 & 2.25 \\
\hline $\mathrm{Abc}$ & 6 & -8 & 5 & 6 & 2.25 \\
\hline
\end{tabular}

Tabel 15

ANOVA untuk Cacat Jahitan dengan Metode Yates

\begin{tabular}{crrrr}
\hline $\begin{array}{c}\text { Sumber } \\
\text { Variasi }\end{array}$ & DK & \multicolumn{1}{l}{ JK } & \multicolumn{1}{l}{ KT } & F \\
\hline $\begin{array}{c}\text { Rata-rata } \\
\text { Perlakuan }\end{array}$ & 1 & 1089 & 1089 & \\
\hline $\mathrm{A}$ & 1 & 132.25 & 132.25 & 48.62 \\
\hline $\mathrm{B}$ & 1 & 49 & 49 & 18.01 \\
\hline $\mathrm{AB}$ & 1 & 2.25 & 2.25 & 0.83 \\
\hline $\mathrm{C}$ & 1 & 20.25 & 20.25 & 7.44 \\
\hline $\mathrm{AC}$ & 1 & 1 & 1 & 0.37 \\
\hline $\mathrm{BC}$ & 1 & 2.25 & 2.25 & 0.83 \\
\hline $\mathrm{ABC}$ & 1 & 2.25 & 2.25 & 0.83 \\
\hline Kekeliruan & 8 & 21.75 & 21.75 & \\
\hline Jumlah & 16 & 1320 & & \\
\hline
\end{tabular}

Dari perhitungan general linear univariate dengan SPSS, diketahui bahwa jika konsentrasi tinggi yang digunakan untuk memproduksi sepatu, jumlah defect yang dihasilkan lebih sedikit jika 
dikerjakan dengan cahaya 40 watt dibandingkan dengan 20 watt. Begitu pula dengan konsentrasi rendah, jika menggunakan cahaya 40 watt, jumlah defect yang dihasilkan lebih sedikit, dibanding menggunakan cahaya 20 watt.

\section{Design Experiment untuk Sol Tidak Lengket}

Di bawah ini adalah hasil pengamatan cacat sol tidak lengket karena pencampuran lem, suhu mesin, dan konsentrasi dengan dua replikasi (tabel 16).

Tabel 16

Hasil Pengamatan Cacat Sol Tidak Lengket karena Pencampuran Lem, Suhu Mesin, dan Konsentrasi dengan Dua Replikasi

\begin{tabular}{ccccc}
\hline Faktor & \multicolumn{4}{c}{ Suhu Mesin } \\
\hline \multirow{3}{*}{ Konsentrasi Rendah } & \multicolumn{3}{c}{$\mathbf{8 0}^{\circ} \mathbf{C}$} & \multicolumn{2}{c}{$\mathbf{8 5}^{\circ} \mathbf{C}$} \\
\cline { 2 - 5 } & \multicolumn{1}{c}{ Pencampuran Lem } & Pencampuran Lem \\
\cline { 2 - 5 } & Encer & Kental & Encer & Kental \\
\cline { 2 - 5 } & 9 & 8 & 10 & 7 \\
\cline { 2 - 5 } & 7 & 6 & 11 & 8 \\
\hline Jumlah & 16 & 14 & 21 & 15 \\
\hline \multirow{2}{*}{ Konsentrasi Tinggi } & 4 & 2 & 9 & 6 \\
\cline { 2 - 5 } & 5 & 1 & 6 & 7 \\
\hline Jumlah & 9 & 3 & 15 & 13 \\
\hline
\end{tabular}

Keterangan: A (Konsentrasi), B (Suhu Mesin), C (Pencampuran Lem)

Maka Hasil Respon: $\quad(1)=16 \quad a=9 \quad b=21 \quad c=14$

$\mathrm{Ab}=15 \quad \mathrm{ac}=3 \quad \mathrm{bc}=15 \quad \mathrm{abc}=13$

Selanjutnya, penentuan kontras untuk cacat sol tidak lengket dengan metode Yates dapat dilihat pada Tabel 17, dan Anova-nya dapat dilihat pada Tabel 18.

Tabel 17

Penentuan Kontras untuk Cacat Sol Tidak Lengket dengan Metode Yates

\begin{tabular}{cccccc}
\hline Faktor & Hasil Respon & Kolom (1) & Kolom (2) & Kontras & JK \\
\hline$(1)$ & 16 & 25 & 61 & 106 & 702.25 \\
\hline $\mathrm{A}$ & 9 & 36 & 45 & -26 & 42.25 \\
\hline $\mathrm{B}$ & 21 & 17 & -13 & 22 & 30.25 \\
\hline $\mathrm{AB}$ & 15 & 28 & -13 & 10 & 6.25 \\
\hline $\mathrm{C}$ & 14 & -7 & 11 & -16 & 16 \\
\hline $\mathrm{Ac}$ & 3 & -6 & 11 & 0 & 0 \\
\hline $\mathrm{Bc}$ & 15 & -11 & 1 & 0 & 0 \\
\hline $\mathrm{Abc}$ & 13 & -2 & 9 & 8 & 4 \\
\hline
\end{tabular}

Tabel 18

ANOVA untuk Cacat Sol Tidak Lengket dengan Metode Yates

\begin{tabular}{ccrrr}
\hline Sumber Variasi & DK & \multicolumn{1}{c}{ JK } & \multicolumn{1}{c}{ KT } & \multicolumn{1}{c}{ F } \\
\hline Rata-rata Perlakuan & 1 & 702.25 & 702.25 & 0 \\
\hline A & 1 & 42.25 & 42.25 & 2.90 \\
\hline B & 1 & 30.25 & 30.25 & \\
\hline AB & 1 & 6.25 & 6.25 & \\
\hline
\end{tabular}




\begin{tabular}{ccrr}
\hline $\mathrm{C}$ & 1 & 16 & 16 \\
\hline $\mathrm{AC}$ & 1 & 0 & 0 \\
\hline $\mathrm{BC}$ & 1 & 0 & 0 \\
\hline $\mathrm{ABC}$ & 1 & 4 & 4 \\
\hline Kekeliruan & 8 & 11 & 1.38 \\
\hline Jumlah & $\mathbf{1 6}$ & $\mathbf{8 1 2}$ & \\
\hline
\end{tabular}

Dari perhitungan general linear univariate dengan SPSS, diketahui bahwa pencampuran lem yang kental, dengan konsentrasi rendah memiliki jumlah defect yang banyak dibandingkan dengan konsentrasi yang tinggi. Selain itu jika konsentrasi tinggi digunakan untuk memproduksi sepatu, maka jumlah defect yang dihasilkan lebih sedikit jika dikerjakan dengan suhu mesin $80^{\circ} \mathrm{C}$ dibandingkan $85^{\circ} \mathrm{C}$. Begitu pula dengan konsentrasi rendah, jika menggunakan suhu mesin $80^{\circ} \mathrm{C}$, jumlah defect yang dihasilkan lebih sedikit, dibandingkan suhu mesin $85^{\circ} \mathrm{C}$.

\section{Design Experiment Kulit Mengkerut}

Di bawah ini adalah hasil pengamatan cacat kulit mengkerut dengan faktor ketahanan kulit dan kelembapan (Tabel 19).

Tabel 19

Hasil Pengamatan Cacat Kulit Mengkerut Karena Ketahanan Kulit, Kelembaban dengan Dua Replikasi

\begin{tabular}{ccc}
\hline \multirow{2}{*}{ Faktor } & \multicolumn{2}{c}{ Kelembaban } \\
\cline { 2 - 3 } & $\mathbf{2 5}^{\circ} \mathbf{C}$ & $\mathbf{2 8}^{\mathbf{C}} \mathbf{C}$ \\
\hline \multirow{2}{*}{ Ketahanan kulit 2 Minggu } & 3 & 5 \\
\cline { 2 - 3 } & 2 & 5 \\
\hline Jumlah & 5 & 10 \\
\hline Ketahanan kulit 3 Minggu & 6 & 9 \\
\hline Jumlah & 6 & $\mathbf{1 6}$ \\
\hline
\end{tabular}

Keterangan: A (Ketahanan kulit), B (Kelembaban)

Maka Hasil Respon: (1) $=5$ $a=12 \quad b=10$

$\mathrm{ab}=16$

$\mathrm{JK}(\mathrm{A})=21.13$

$\mathrm{JK}(\mathrm{B})=10.13$

$\mathrm{JK}(\mathrm{AB})=0.13$

Selanjutnya penentuan kontras untuk cacat kulit mengkerut dapat dilihat pada Tabel 20,serta Anova-nya (Tabel 21).

Tabel 20

Penentuan Kontras untuk Cacat Kulit Mengkerut dengan Metode Yates

\begin{tabular}{ccccc}
\hline Perlakuan & Hasil Respon & Kolom (1) & Kolom (2) & JK \\
\hline$(1)$ & 5 & 17 & 43 & 231.13 \\
\hline $\mathrm{A}$ & 12 & 26 & 13 & 21.13 \\
\hline $\mathrm{B}$ & 10 & 7 & 9 & 10.13 \\
\hline $\mathrm{AB}$ & 16 & 6 & 1 & 0.13 \\
\hline
\end{tabular}


Tabel 21

ANOVA untuk Cacat Kulit Mengkerut dengan Metode Yates

\begin{tabular}{ccccc}
\hline $\begin{array}{c}\text { Sumber } \\
\text { Variasi }\end{array}$ & DK & JK & KT & F \\
\hline $\begin{array}{c}\text { Rata-rata } \\
\text { Perlakuan }\end{array}$ & 1 & 231.13 & 231.13 & \\
\hline $\mathrm{A}$ & 1 & 21.13 & 21.13 & 34.08 \\
\hline $\mathrm{B}$ & 1 & 10.13 & 10.13 & 16.34 \\
\hline $\mathrm{AB}$ & 1 & 0.13 & 0.13 & 0.21 \\
\hline Kekeliruan & 4 & 2.48 & 0.62 & \\
\hline Jumlah & 8 & 265 & & \\
\hline
\end{tabular}

Dari perhitungan dengsn SPSS diketahui untuk ketahanan kulit dua minggu, dengan kelembaban $25^{\circ} \mathrm{C}$ memiliki jumlah defect yang sedikit dibandingkan dengan $28^{\circ} \mathrm{C}$. Selain itu jika menggunakan kulit dengan ketahanan hingga tiga minggu untuk memproduksi sepatu, jumlah defect yang dihasilkan lebih sedikit jika dikerjakan dengan kelembaban $25^{\circ} \mathrm{C}$ dibandingkan dengan menggunakan kelembaban $28^{\circ} \mathrm{C}$.

\section{Tahapan Control}

\section{Standard Operational Procedure}

Pembuatan SOP dilakukan berdasarkan rumusan penyebab dan sebab serta faktor-faktor lain yang berperan dalam mempengaruhi kinerja karyawan. Tabel 22 memperlihatkan contoh SOP untuk melakukan control terhadap cacat jahitan.

Tabel 22

SOP untuk Meminimalisasi Cacat Jahitan

\begin{tabular}{ccccccc}
\hline Tanggal & No & Kegiatan & F & Inspector & \multicolumn{2}{c}{ Deskripsi } \\
\hline 13 April & 1 & $\begin{array}{c}\text { Memeriksa } \\
\text { kondisi lampu }\end{array}$ & 1 & $\mathrm{X}$ & $\begin{array}{c}\text { Lampu 40 } \\
\text { watt menyala } \\
\text { dengan baik }\end{array}$ & $\sqrt{ }$ \\
\hline 14 April & 2 & $\begin{array}{c}\text { Memeriksa } \\
\text { kualitas } \\
\text { benang }\end{array}$ & 2 & A & Baik & $\sqrt{ }$ \\
\hline 15 April & 3 & $\begin{array}{c}\text { Pengarahan } \\
\text { pada operator }\end{array}$ & 1 & $\mathrm{X}$ & - & $\sqrt{ }$ \\
\hline
\end{tabular}

\section{PENUTUP}

Dari pembahasan yang telah dilakukan, dapat ditarik beberapa kesimpulan, yaitu: (1) tipe sepatu Cheetah adalah tipe sepatu yang dianggap paling bermasalah berdasarkan nilai sigma; (2) cacat dominan yang muncul pada saat proses perakitan sepatu Cheetah adalah cacat jahitan, sol sepatu tidak lengket dan kulit mengkerut; (3) kestabilan proses untuk perakitan tipe Cheetah masih dinilai kurang baik (Cp sebelum implementasi adalah 0.95825); (4) kesalahan yang terjadi pada cacat jahitan sangat minim apabila operator bekerja dengan konsentrasi tinggi, dengan menggunakan cahaya 40 watt dan kualitas benang tebal. Selanjutnya, kesalahan pada cacat kulit mengkerut sangat minim apabila operator bekerja dengan kelembaban $25 \mathrm{C}$ dan menggunakan ketahanan kulit maksimal sejak dua 
minggu sebelum diproses. Kemudian, kesalahan pada sol tidak lengket sangat minim apabila operator bekerja dengan konsentrasi tinggi, menggunakan suhu mesin $80 \mathrm{C}$ dan pencampuran lem kental; (5) human error - mesin chillers memiliki temperatur kurang tinggi dan kualitas material dari supplier merupakan faktor penyebab dominan cacat produk.

\section{DAFTAR PUSTAKA}

Ariani, Dorothea Wahyu (1999). Manajemen Kualitas (edisi 1). Yogyakarta: Universitas Atma Jaya.

Montgomery, Douglas C. (2002). Introduction to Statistical Quality Control. New York: John Wiley $\&$ Sons.

Pande, Peter S., Neuman, Robert P., Cavanagh, Ronald R. (2003). The Six Sigma Way: Bagaimana GE, Motorolla, dan Perusahaan Terkenal Lainnya Mengasah Kinerja Mereka. Yogyakarta: Andi.

ST, Miranda. (2002). Six Sigma: Gambaran Umum, Penerapan Proses dan Metode-Metode yang Digunakan untuk Perbaikan GE Motorolla. Jakarta: Harvarinda. 